\title{
Simulation of suburban migration: driving forces, socio-economic characteristics, migration behaviour and resulting land-use patterns
}

\section{Wolfgang Loibl}

\begin{abstract}
Land-use transitions in metropolitan areas have a high impact on environment and appear as pressures on the inhabitants' living conitions. Tools are needed to support planning decisions to overcome or at least mitigate those pressures. Simulation models are such tools, generating land-use change scenarios that help to examine effects of planning strategies. This article introduces a model that establishes a multiagent system approach to achieve results for changes in land-use and migration patterns with high spatial accuracy.

Details of suburban migration behaviour modelling are described with emphasis on the definition of socio-economic classes, on the detection of driving forces triggering suburban migration and on migration behaviour aspects with respect to those socio-economic classes. The model concept is presented as well as results of retrospective simulation runs for a 30-year time range that are compared with the observations of the simulation target year in order to examine the model's validity. Future scenario runs show different urban sprawl trends with either restricted or unlimited residential area zoning and higher versus lower target residential density regulations. A remarkable decrease of suburban sprawl can be achieved by applying the right planning measures, even if the numbers of migrating households remain the same.
\end{abstract}

\section{Introduction}

\subsection{Suburbanisation as major environmental pressure}

Suburbanisation has for decades been the major landscape transition process in Europe's metropolitan areas. Suburbanisation is the decentralisation of living, service, production, and of transportation activities moving from core cities to the outskirts, creating new patterns of population distribution, new patterns of land utilisation and increasing traffic.

The extension of suburban built-up areas is based on population growth driven by new residents searching for attractive residential areas and fuelled by enterprise start-ups in highly accessible areas in appropriate distance to the core city near motorway exits. The growth of suburban population and the increasing dispersion of 
residential areas and commercial facilities lead to an increase of traffic levels, because of increasing average travel distances and trip numbers. Landscape attractiveness and the accessibility of the core city, rather than distance to it, might increasingly influence future decisions about living places or company locations. Thus the major suburban environmental pressures are loss of open space and increasing traffic (cf. Batty et al. (2003), Brake et al. (2001), Cheshire et al. (1999)).

Urban planning and regional development plans need scenario results as a basis for decision-making to foresee potential environmental threats as a consequence of inappropriate planning activities or to show the effects of strategies designed to mitigate unfavourable impacts of suburbanisation.

\subsection{Migration to the suburbs as one major reason of suburbanisation}

This research contributes to regional planning activities designed to mitigate metropolitan area sprawl. During the last years we have developed a model that allows the simulation of suburban land-use change based on suburban in-migration and commercial start-ups, considering the effects of different local zoning and housing density regulations.

The model deals mainly with the growth of residential and commercial built-up areas. To simulate suburban land-use change patterns with high spatial accuracy, the diversity of the many moving household and entrepreneurial decisions have to be taken into account. The model simulates effects of migration surplus and does not consider intra-regional migration which is leading to "population exchange" but is not contributing to residential area growth. Besides in-migrating households, weekend house buyers also cause land-use change referring to residential areas. But weekend house seekers do not contribute to the resident population number growth and enterprise start-ups in the suburban regions do not much affect suburban population migration. As this book refers to demographic aspects, the article addresses specifically those tasks that are related to demographics and migration causing residential area growth.

\subsection{Driving forces of suburban in-migration}

Suburban in-migration is understand as migration flows caused by people that have left their native town (in the majority the core city) to settle in one of the suburban municipalities. There exist several population migration theories and migration modelling concepts (cf. Goetz (2003), Lienenkamp (1999), Stillwell and Congdon (1991) for comprehensive overviews).

Explanations of migration refer mostly to the following basic approaches:

- Simple mechanistic approaches like the gravity model, based on Newton's Law of Gravity, explain or calculate migration flows just by migration distance and population numbers at the origins and targets of the migration flows (cf., e. g., 
Haynes and Fotheringham (1984)). They are somehow outdated as they are valid only in a very rough manner referring to long-distance migration flows between large spatial entities.

- A systems-theoretical, macro-analytical approach describes migration patterns, where the overall effect on (spatial) entities is examined by ,objective“, structural criteria. Focusing on this approach, explanations often remain mono-causal. (Lienenkamp (1999))

- A behavioural, micro-analytical approach explains migration behaviour, taking into account desires, necessities, demands and motives triggered by personal and social relations, but usually do not consider spatial aspects. (Lienenkamp (1999))

Accurate spatial simulation of suburban migration patterns and of migration-related spatial effects requires taking into account individual migration behaviour. Thus one has to refer to behavioural migration theories for developing an appropriate model. The push-pull theory prepared by several authors-among them Bogue (1969) - delivers an appropriate explanation framework in order to create a proper simulation model for (general and suburban) migration simulation. The overall paradigm is that migration is caused by regional disparities of various attractiveness criteria between the origin and the destination region, the actors' dissatisfaction with the actual state and a realistic opportunity improving future living conditions- push and pull factors provoke migration:

- push factors push migrants to move because of disadvantageous living conditions.

- pull factors pull migrants to decide between competing destinations with better living conditions.

For large-distance migration mostly economy-related reasons are of major importance. The criteria for selecting a distant migration target are: offer of well-paid labour and availability of flats. As the chance is higher to gather both in large cities than in small towns or rural areas, targets for large-distance migration are usually larger core cities. (cf. Lienenkamp (1999)).

Concerning small-distance suburban migration, the majority perception of core city inhabitants is that living conditions in the core city are unfavourable. Thus improvement of living conditions (while keeping the work place) is the main motive to seek a new residential area in the outskirts (cf. Landale and Guest (1985), Lee et al. (1994), Kearns and Parkes (2002)). Thus the important reasons for suburban migration refer to the housing/living condition sphere and partly to social sphere and changing family demands shown in table 1 . Social sphere-related desires vary very much with respect to personal and social circumstances that cannot be considered by such models without very detailed data regarding single household structure and single migration movements. Therefore the author concentrates on the housing/living condition sphere as major driving force pool for migration target decisions. 
Table 1: The general driving forces of migration:

\begin{tabular}{|c|c|c|}
\hline Reasons & Push-factors & Pull-factors \\
\hline $\begin{array}{l}\text { Economical } \\
\text { sphere }\end{array}$ & $\begin{array}{l}\text { - economical disadvantages } \\
\text { (salaries, lack of services/goods demand) } \\
\text { - unemployment (both rarely relevant for } \\
\text { city-suburb migration) }\end{array}$ & $\begin{array}{l}\text { - employment opportunities } \\
\text { - salaries (both rarely relevant for } \\
\text { city-suburb migration) }\end{array}$ \\
\hline Social sphere & $\begin{array}{l}\text { - end of professional education } \\
\text { - change of job } \\
\text { - increase of personal income, } \\
\text { - change in family status } \\
\text { (marriage, children...) } \\
\text { - } \text { social neighbourhood structure }\end{array}$ & $\begin{array}{l}\text { - more appropriate social neighbourhood } \\
\text { structure }\end{array}$ \\
\hline $\begin{array}{l}\text { Housing / living } \\
\text { condition sphere }\end{array}$ & $\begin{array}{l}\text { dissatisfaction with neighbourhood: } \\
\text { - little green space } \\
\text { - much traffic/noise } \\
\text { - small apartments } \\
\text { - few social, educational, leisure time } \\
\text { facilities/opportunities } \\
\text { - expensive flats, houses, lots } \\
\text { - general lack of other flats, houses, lots }\end{array}$ & $\begin{array}{l}\text { - nice neighbourhood and surroundings } \\
\text { - } \text { sufficient and appropriate housing supply } \\
\text { - little traffic /noise } \\
\text { - good general accessibility to major road } \\
\text { network (short commuting distance) } \\
\text { - supply of appropriate (\& less expensive) } \\
\text { flats, houses, lots } \\
\text { - good social, education, leisure facilities }\end{array}$ \\
\hline
\end{tabular}

Concept referring to Bogue (1969) and Lienenkamp (1999)

\section{Model approach to simulate suburban migration and residential area growth}

\subsection{Multi-agent modelling basics for migration simulation}

Traditional (macro-scale) models are ineffective in handling micro-scale phenomena (Torrens (2001)). To simulate suburban residential area growth with high spatial accuracy, the model must consider the diversity of migration decisions of the potential migrants. Following a behavioural modelling approach, migration patterns and land-use change are the result of many individual actors' activities. When modelling individual activities, this diversity of migration decisions leading to the observed complex migration patterns can be simulated in detail. Spatial environment is perceived and judged by actors who live in the environment and who-according to their (varying) perceptions and desires — behave and act differently within this region (cf. Ruppert and Schaffner (1969)). Thus multi-agent systems are expected to be ideal for modelling regional development, as agents are "systems situated within and part of an environment that sense that environment and act on it, over time." (Franklin and Graesser (1996)). Therefore an agent-based model approach was selected that simulates the actors' behaviour as reactions to push and pull factors. In our 
case agents react to environmental disadvantages (mostly in the core cities) by responsive behaviour to overcome discrepancies between the housing conditions in the migrants' current residential area and desires regarding the future residential area.

There exist several multi-agent system models (often combined as a hybrid model with cellular automata) from various authors who simulate land-use change (cf. Portugali (1999), Torrens (2001); Batty et al. (2003)). They are often market- and (mostly) neighbourhood-oriented and concentrate on steady core city growth. Settlement growth in poly-centred large suburban regions has not been introduced in detail by those concepts. The presented model does not consider home buyer and seller aspects as it concentrates on migration target search of singe households into the core-city surroundings and the occupation of new lots in those target municipalities. Here a general willingness is assumed to sell vacant and appropriate lots, as observed in the past. The model strives to perform a detailed growth simulation of scattered suburban settlements that grow at different intensities and speeds. The different growth speed is based on various pull factor patterns defined as attractiveness which trigger the different decisions of a large number of actors integrated into the model as agents.

\subsection{Simulation concept of the developed model}

The residential area growth simulation presented here is based on household migration and consists of two major tasks that start after a preparation task. This preparation task defines the reservoir of migrating agents which represent single households, at present with an average household size of 3 persons. The decision where to move depends on the agents' knowledge about the potential target region, on regional and local attractiveness patterns and the households' desires and (financial) constraints. The set of moving households is divided into 4 different socio-economic household categories, with different migration behaviour with respect to target municipality choice and residential area selection, which will be described later.

The migration activity of each household is assumed to be carried out by two decision steps that refer first to municipality choice and then to residential area search.

\section{Task 1: municipality choice:}

As mentioned above the agents' choice of a migration target is assumed to be driven by regional pull factors. So the first step is to examine the municipalities regarding certain pull factor patterns and possible matches with agents' migration behaviour. Referring to the municipality choice of different agent classes, it can be expected that certain municipalities are selected more often than others. The municipality selection is carried out by random choice of a municipality within the agent class's specific target municipality choice probability distribution. 


\section{Task 2: residential area search}

The agents' search of a residential area within the selected target municipality is assumed to be triggered by local pull factors. The local search takes place within a "cellular world" where all cells contain information about various spatial characteristics. The search starts in a random cell within the selected municipality in different ways depending on different agent types. During the search, the agents are moving within the municipality's residential area, looking for an appropriate target cell. The cells' suitability for housing depends on the respective pull factors and the importance weights as judged by the moving households.

Fig 1 shows the overall model in which the migration model is embedded:

Fig. 1:

Concept of suburban land-use change simulation

(Loibl and Tötzer (2003))

\section{Model tasks, elements:}

Initialisation

\begin{tabular}{l}
$\begin{array}{l}\text { Population, } \\
\text { employment } \\
\text { forecast }\end{array}$ \\
\hline
\end{tabular}

national population dynamics -

regional migration balance regional employment numbers

\section{Model action:}

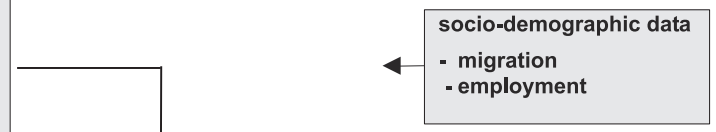

Task 1 - Municipality choice

\begin{tabular}{|c|c|c|c|}
\hline $\begin{array}{l}\text { Spatial } \\
\text { agent } \\
\text { model }\end{array}$ & $\begin{array}{l}\text { Agents: } \\
\text { - perception } \\
\text { - desire/limitation } \\
\text { - decision } \\
\text { - action }\end{array}$ & $\begin{array}{l}\text { Municipality choice - model: } \\
\text { target choice probability }\end{array}$ & $\begin{array}{l}\text { regional attractiveness: } \\
\text { - landscape } \\
\text { - accessibility } \\
\text { - services supply } \\
\text { - land prices / rents }\end{array}$ \\
\hline \multicolumn{4}{|c|}{$\begin{array}{l}\text { Task } 2 \text { Residential area } \\
\text { search }\end{array}$} \\
\hline $\begin{array}{l}\text { Spatial } \\
\text { agent } \\
\text { model }\end{array}$ & $\begin{array}{l}\text { Agents: } \\
\text { - perception } \\
\text { - desire } \\
\text { Landscape }\end{array}$ & $\begin{array}{l}\text { Agents' allocation } \\
\text { Landscape transition: } \\
\text { new built-up area/ } \\
\text { densification }\end{array}$ & $\begin{array}{l}\text { local attractiveness: } \\
\text { - population density } \\
\text { - zoning } \\
\text { - land use, ..... }\end{array}$ \\
\hline
\end{tabular}

The decision, of each agent, where to settle is influenced by actions of previous migrants as they have caused new population densities and land-use patterns. Each agent's action changes local attractiveness and influences the decision of future moving agents. A "software blackboard" allows to send and receive messages between the agents so new movers can learn from the experience of previous successful movers. The effect of the blackboard is that it leads to less (stochastic) spread of new residential area within a municipality as new movers search in a first step near "landscape cells" where movers have already settled successfully. Thus the pattern of newly occupied lots within a municipality is less scattered, as observed in reality. 


\subsection{Study area and employed datasets}

The model was developed within the project "STAU-Wien" dealing with Vienna core city - suburb relations (Loibl et al. (2002)). One of the project's objectives was the simulation of suburban land-use change within the Greater Vienna region. The study area covers 180 municipalities surrounding the core city within a $30-\mathrm{km}$ radius (see Fig. 2). The spatial effect of suburbanisation is principally the increase of built-up area which includes residential areas and commercial lots. The model handles the growth of both residential and commercial built-up areas but this article concentrates on residential area growth simulation.

As in-migration is the main reason of residential area growth, a migration model is a major task within a land-use change model to provide results with sufficient spatial accuracy. The migration model uses population data on a census unit level with 680 suburban census units and migration interaction data on a municipality level for the 180 municipalities. Gridded land-use maps for different years are applied as land-use transition layers to simulate built-up area growth on a cell-by-cell basis. The land-use maps with $100 \times 100 \mathrm{~m}$ cell size were derived from satellite images 1968 and 1999 (Steinnocher et al., 2000). A detailed road network was applied for accessibility calculations (travelling time to the suburban central places and to the core city). Further datasets contain additional spatial characteristics quantifying residential suitability on a regional and local scale. To allow detailed cell-based simulation, population numbers per census unit are referred to the residential area cells within the respective census units.

Fig. 2:

Greater Vienna region study area

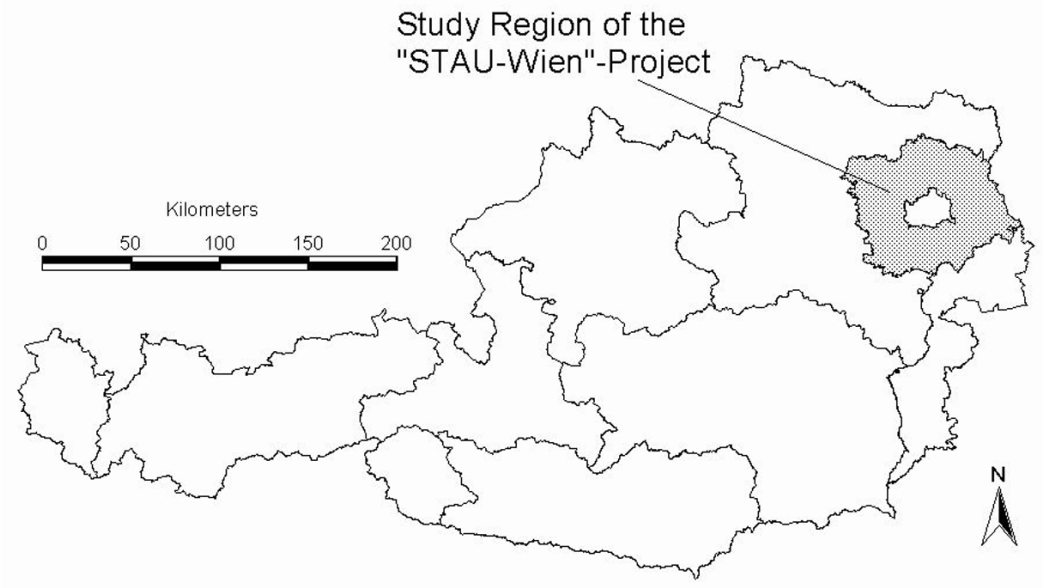

The time range of the "control run" simulation is 1968 to 1999 using available satellite images for validation. Table 2 shows the growing population numbers within 
the core city and its surroundings which are available for all census years 1971 to 2001 serving as base data for migration simulation: a suburban population growth of 120.000 people $(24 \%)$ can be observed during these 3 decades. (Forecast scenario runs were carried out for 2011 but are not discussed in detail here.)

Tab. 2: Population in the Greater Vienna region

\begin{tabular}{|l|c|c|c|c|}
\hline & $\mathbf{1 9 7 1}$ & $\mathbf{1 9 8 1}$ & $\mathbf{1 9 9 1}$ & $\mathbf{2 0 0 1}$ \\
\hline Vienna core city & 1.620 .000 & 1.530 .000 & 1.540 .000 & 1.560 .000 \\
\hline Suburban study area & 500.000 & 530.000 & 570.000 & 620.000 \\
\hline Greater Vienna region & 2.120 .000 & 2.060 .000 & 2.110 .000 & 2.180 .000 \\
\hline
\end{tabular}

Source: Statistik Austria, population census 1971, 1981, 1991, 2001

The analysis of migration patterns shows certain differences within the entire Greater Vienna region: some outskirt settlements were selected more often as migration targets than others. Figure 3 depicts the net migration balance of the municipalities in the Vienna surroundings where the bars indicate migration numbers for each municipality during 3 decades.

Fig. 3:

Suburban migration balance within the Greater Vienna region

migrating persons

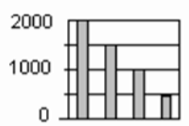

migration balance

1971
$\square$
$\square$

1991

motorways

$A$ railways

municipality borders
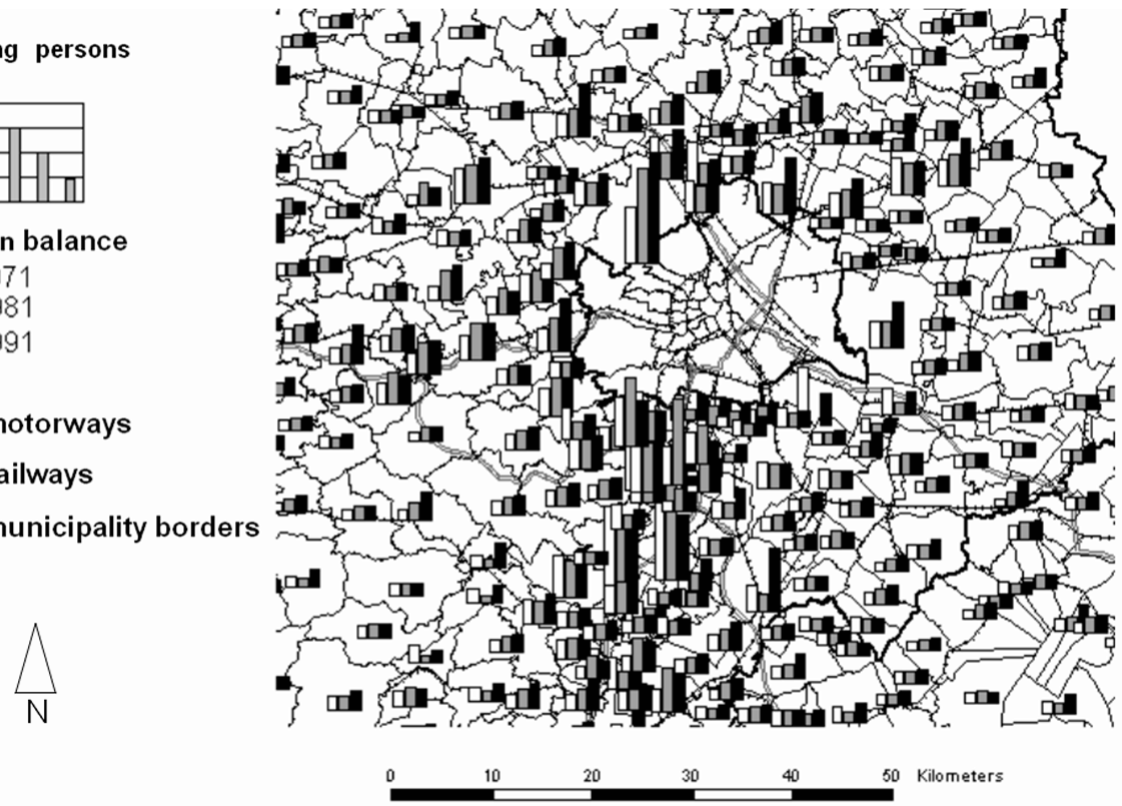
These migration movements have shaped a poly-centred suburban settlement growth pattern with different growth intensities. Several in-migration "hot spots" can be observed: the highest growth concentration is south of Vienna in attractive areas between the Wienerwald ridges - a popular, attractive forested recreation area, and the Südbahn railway route as well as the A2 motorway, both providing fast access to the Vienna core city.

\subsection{Modelling pull factors for target municipality choice}

Referring to Bogue, (1969) push and pull factors provoke peoples' movement-in our case from core cities to suburban municipalities. Those factors have to be detected and verified:

- Push factors that interfere with individual life quality as observed in the core cities are increasing rents and land prices, increasing housing densification, increasing traffic and, accordingly, decreasing environmental (and perhaps social) quality. As we do not simulate origin-destination migration interactions at the individual level but only in-migration to suburban municipalities, the push factor patterns are not taken into account as drivers to select a particular target. Overall push-factor gradients are assumed that reflect higher pressures in the core city and lower pressures in the suburban surroundings.

- Pull factors attract migrants to decide in favour of a certain municipality. They have to be examined in detail as polycentric growth dynamics seem to be dependent on regional attractiveness patterns within the suburban areas neighbouring the core city, which induce different population dynamics and thus land-use change. The individual migration-target choice is triggered by desires regarding residential area attractiveness influenced by socio-economic characteristics and financial constraints of the migrants, who react on those attractiveness patterns.

In order to quantify suburban in-migration probabilities, selected regional attractiveness patterns are derived and referred to migration patterns. Several landscape attractiveness layers are generated as grid cell data sets (see Fig. 4) and then averaged for the target municipalities to quantify their attractiveness as future migration targets (Loibl and Kramar (2001)):

- Landscape attractiveness layers are quantified applying the land-use maps of the simulation start year and using a digital elevation model. Some proxy data are generated: the quota of attractive areas like forests in the vicinity of residential areas or scenic attractiveness derived as elevation range in the surroundings of a municipality.

- Local services supply is quantified by several indicators, derived from the number of facilities of certain services and the distance between the facilities and the residential areas of the respective municipalities. Attorneys, tax consultants, special- 
ist medical practitioners and grammar schools are considered as proxy data for those local services supply quality.

- Core city accessibility is calculated by applying a shortest-path model to find the minimum travel time to the Vienna city centre. As travel distance is changing over time, accessibility maps are generated for several years: 1971, 2001 and 2015 (the last one by integrating future motorways in the road network)

- Residential lot prices are provided as proxy data for housing costs from estate trading statistics. As no time series of land price data is available, it is assumed that the land price differences between the various municipalities remain static over time.

- Availability of lots information is provided as a map layer of zoned but still vacant residential areas observed in the simulation start year.

The assumed dependences of population growth and residential area growth on attractiveness patterns have to be verified. The test is performed by linear regression models using the net migration number at target $i$ as predictor variable $m_{i}$ and various attractiveness criteria as explanatory variables. Regression functions are estimated to explain the in-migration movements 1971-1981 and 1981-1991 of the relevant municipalities. The variables finally selected are those explanatory variable combinations where the modelled migrant numbers show the highest correlation with observed net migrant numbers: the correlation coefficients $\mathrm{R}^{2}$ of the tested regression results vary between 0.67 and 0.88 for different decades which proves a high dependence between migration patterns and attractiveness variables. The general model finally selected with the highest explanatory value is (cf. Loibl and Kramar (2001)):

$$
m_{i}=d_{c i} x_{d}+l_{i} x_{l}+s_{i} x_{s}+a_{i} x_{a}
$$

where

$m_{i}$, = net migration number of each suburban target municipality $i$

$d_{c i}$, $=$ distance (accessibility) between core city $c$ and suburban target municipality $i$

$l_{i}=$ landscape attractiveness at target municipality $i$ (forest area quota in the neighbourhood)

$s_{i}=$ services supply at target municipality $i$ (service potential, i. e., availability, number and access, of grammar schools, attorneys, tax consultants, specialist medical practitioners, hospitals)

$a_{i}=$ availability of lots, houses at target municipality $i$. (vacant cells with residential area zoning)

$x=$ regression coefficients for the variables $d, l, s$ and $a$.

The increase of core city commuters shows high correlation with the in-migration numbers, which verifies the assumption that suburban in-migrants remain working in the core city and appear to be rather flexible concerning commuting necessities. Local employment opportunities do not play a major role for the search of future sub- 
urban migration targets and are thus not included into the regression models. Land prices are not integrated in the final regression functions because they are directly dependent on the demand of migrants, but they are integrated in the target municipality selection process as decision threshold to consider socio-economic constraints of different household classes. Figure 4 shows the spatial patterns of some regional attractiveness criteria.

Fig. 4:

Regional attractiveness for suburban migration target choice (Loibl and Kramar (2001))
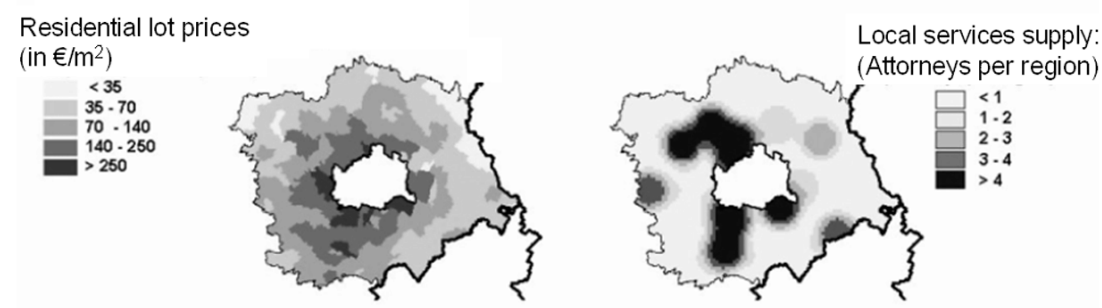

Landscape attractiveness:
Neighbourhood forest area (in \%)
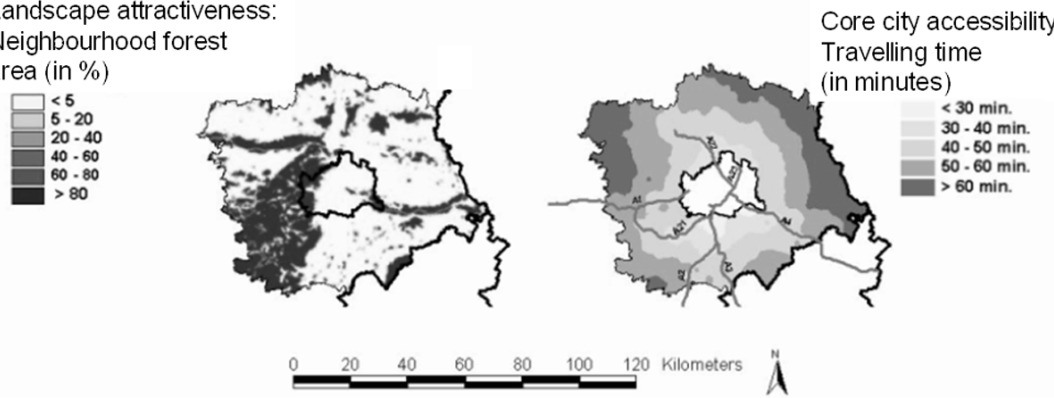

\subsection{Detecting municipality choice frequency patterns for socio-economic classes}

Empirical analyses show that socio-economic status definitely influences residential area choice (cf. By og Byk (2003), Loibl and Kramar (2001) and Portugali (1999)). The migrating actors have different desires and constraints and thus make different decisions regarding an appropriate future residential area. Socio-economical household classes are defined to cover the range of migration decisions.

To detect differences in target municipality choice by socio-economic classes and refer them to regional attractiveness, the migration matrices of the Greater Vienna region are examined in detail. Education data are used as proxy data, because income data are not available to characterise the socio-economic status and school education highly correlates with income and financial capabilities (cf. Becker (1975). The selected variable for "high education" is grammar school or academic education. 
Table 3 shows the standardised regression coefficients for these two socio-economic classes. The 4 explanatory variables are examined by stepwise regression analysis and are modified slightly to increase the explained variance: instead of the availability of lots, the actual population number serves as the fourth explanatory variable. The highest explanation share can be observed for the municipality's 1991 population numbers and for core city accessibility. Accessibility, landscape attractiveness and service supply are significantly more important for high-educated migrants then for low-educated migrants with (usually) less income.

Tab. 3: Standardised regression coefficients for two socio-economic migrant classes

\begin{tabular}{|l|c|c|c|c|c|}
\hline & $\begin{array}{c}\text { Core city } \\
\text { accessibility }\end{array}$ & $\begin{array}{c}\text { Landscape } \\
\text { attractiveness }\end{array}$ & $\begin{array}{c}\text { Services } \\
\text { supply }\end{array}$ & $\begin{array}{c}\text { Population } \\
1991\end{array}$ & $\mathrm{R}^{2}$ \\
\hline high-educated migrants 81-91 & -0.246 & 0.146 & 0.060 & 0.949 & 0.877 \\
\hline low-educated migrants 81-91 & -0.121 & 0.039 & -0.034 & 0.918 & 0.901 \\
\hline
\end{tabular}

Figure 5 shows the relative municipality choice frequency distribution as observed for 1981-1991-migration (which is the latest available detailed migration data set). The relative frequencies show that migrants with high education/income are concentrating on a small number of attractive targets, while migrants with low education/income show a wider choice diversity.

Fig. 5:

Observed relative municipality choice frequencies of $\mathbf{2}$ socio-economic migrant classes (Sorted by choice frequency of low-educated migrants; the maximum frequency of 0.09 has to be interpreted as " $9 \%$ of the migrants select the respective municipality as migration target")

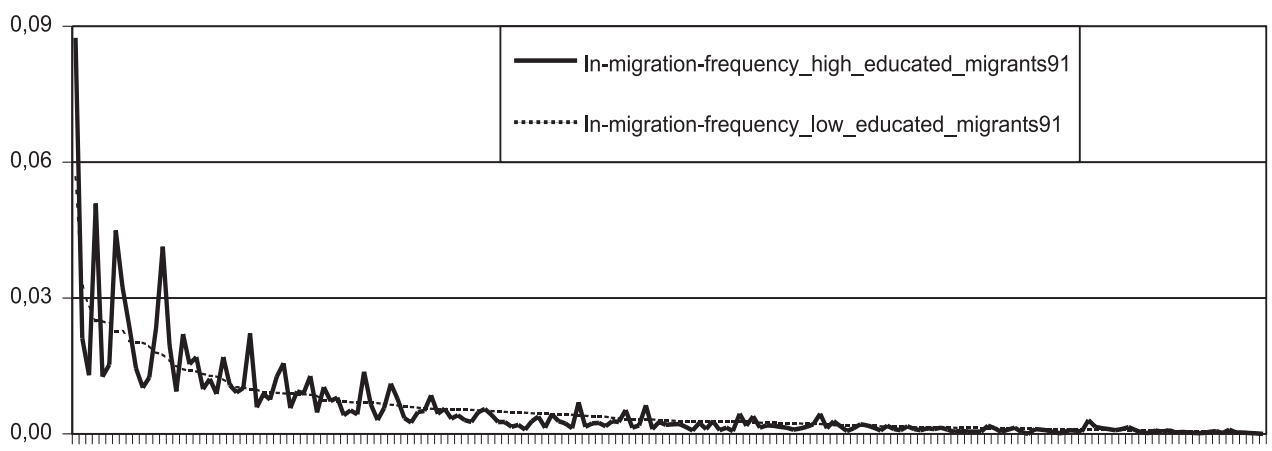

Target municipalities

Figure 6 shows those municipalities with highest target choice frequency and allows to discover the "hot spots" of target choice by migrants with high education/income: the attractive and expensive municipalities which are located adjacent to the attractive and forested Wienerwald hills such as Klosterneuburg, Purkersdorf, Mauerbach, Perchtoldsdorf, Mödling, Baden or Maria-Enzersdorf. 
Fig. 6:

Highest municipality choice frequencies of 2 socio-economic classes: relative frequency $10 \%$ to $1 \%$ (32 municipalities)

(sorted by choice frequency of low-educated migrants)

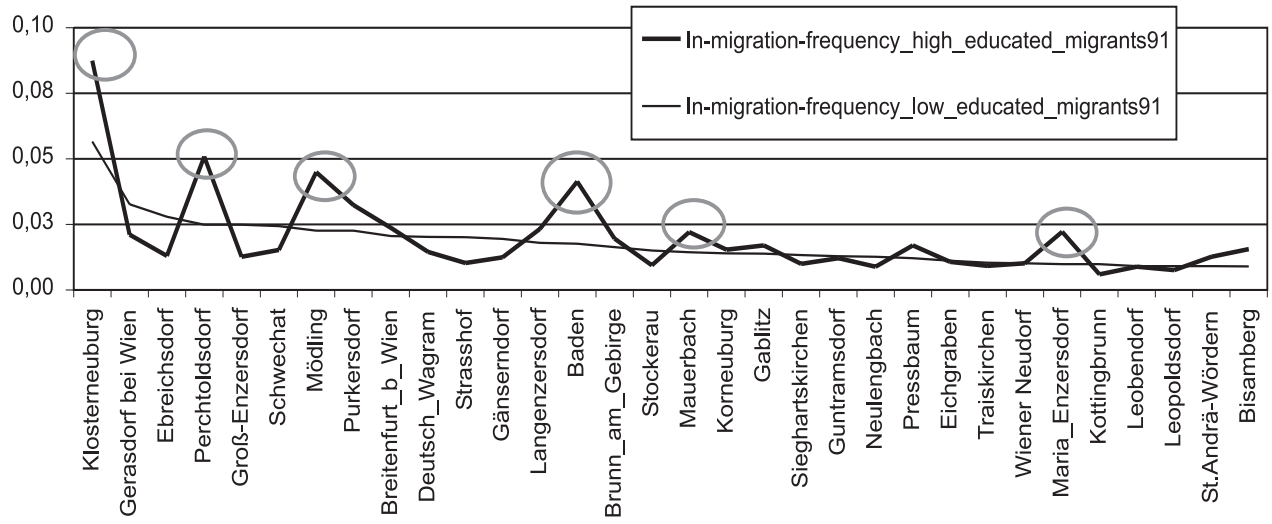

Figure 7 depicts the choice frequency distribution "tail", now sorted by high-educated migrants: while the target choice frequencies of high-educated migrants are consequently decreasing for those municipalities, the target choice frequencies of the low educated migrants remain still higher, allowing the assumption that attractiveness criteria are less important for this socio-economic class, as living space in those areas is less affordable for them.

Fig. 7:

Lowest municipality choice frequencies: relative frequencies below $5 \%$ :

118 of 180 municipalities

(sorted by choice frequency of high-educated migrants)

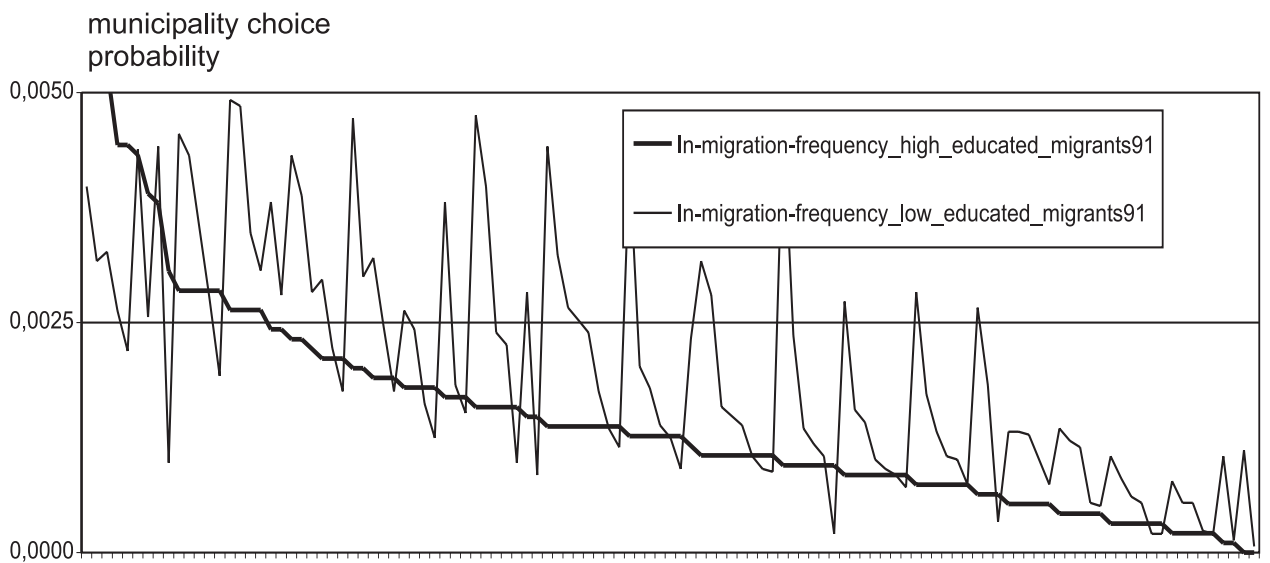

Target municipalities 


\subsection{Calculating municipality choice probability for four socio-economic household agent classes}

The relative municipality choice frequency distribution is estimated by regression models as shown above. In order to define target choice probabilities for each municipality $i$ to perform migration simulation for the preliminary two socio-economic migrant classes, the regression model results for those two classes (Tab. 4) were normalised:

$$
m_{i} \rightarrow m_{i}^{*} .
$$

The sum of all $m^{*}{ }_{i}$ now shows the probability total $\mathrm{P}=1$ containing all suburban migration flows $m_{i}$.

$$
\Sigma m_{i}^{*}=\Sigma p_{i}=\mathrm{P}=1
$$

The municipality choice probability distributions for the 2 household classes are now applied to simulate target municipality selection by individual households: a target municipality is picked by each single household randomly out of the agent class's probability distribution. Municipalities with a higher choice probability will be selected more often than those with a low choice probability. An important issue is that the choice probability distributions are estimated by regression models with regional attractiveness variables quantified for the municipalities. Therefore the probability distributions can be modified for forecast simulation runs applying the regression models with modified explanatory variables.

As mentioned above, household classes were distinguished based on education/income extracted from the Greater Vienna region migration matrices. A distinction of households in life cycle and household size classes is not integrated here. To simplify the model for this first application, an average household size of 3 persons is assumed as standard agent entity. This is a rather coarse assumption as household size changes over time and leads to different claims regarding apartment size, required service infrastructure and attractive surroundings (Loibl et al. (2002)). Household types were defined as agent classes with different demands and decision behaviour regarding residential area as shown in table 4. 
Tab. 4:

Socio-economically defined household classes with different migration behaviour

\begin{tabular}{|l|l|l|}
\hline Household type & $\begin{array}{l}\text { Demand on service infrastructure } \\
\text { and environment quality }\end{array}$ & $\begin{array}{l}\text { House type/residential } \\
\text { area preferences }\end{array}$ \\
\hline $\begin{array}{l}\text { high education, } \\
\text { high income }\end{array}$ & $\begin{array}{l}\text { Good service infrastructure, good } \\
\text { core city accessibility }\end{array}$ & $\begin{array}{l}\text { Desire and ability to afford single family } \\
\text { houses in regions with higher lot prices }\end{array}$ \\
\hline $\begin{array}{l}\text { high education, } \\
\text { medium income }\end{array}$ & $\begin{array}{l}\text { Good service infrastructure, } \\
\text { moderate core city accessibility }\end{array}$ & $\begin{array}{l}\text { Afford and accept flats instead of single } \\
\text { family houses in regions with higher lot } \\
\text { prices and rents }\end{array}$ \\
\hline $\begin{array}{l}\text { low education, } \\
\text { medium income }\end{array}$ & $\begin{array}{l}\text { Average service infrastructure, less } \\
\text { core city accessibility }\end{array}$ & $\begin{array}{l}\text { Desire and ability to afford single family } \\
\text { houses in regions with moderate lot prices }\end{array}$ \\
\hline $\begin{array}{l}\text { low education, } \\
\text { low income }\end{array}$ & $\begin{array}{l}\text { Accept inferior service infrastructure } \\
\text { and core city accessibility }\end{array}$ & $\begin{array}{l}\text { Accept cheap houses or flats in regions with } \\
\text { low lot prices and rents }\end{array}$ \\
\hline
\end{tabular}

In order to consider different migration decisions of single family house seekers and multi-storey flat seekers with high or low income, the two migrant types, differentiated by education, are divided into four socio-economic household-agent classes. The basis of the distinction of migration flows for this four socio-economic classes are the regression model results carried out with the available migration interaction data for the two preliminary socio-economic migrant types (shown in table 3). This distinction regarding municipality choice and residential area selection is based on assumptions which take into account sample questioning in the study area and literature review (cf. Loibl et al. (2002), Horstmann (1976), Landale and Guest (1985), Lee et al. (1994)). Migration behaviour rules were tested within the model by applying different attractiveness thresholds for the four agent classes that overrule the target choice probability distributions and allow the exclusion of several municipalities by some agent classes due to unacceptable attractiveness: e. g., requirements regarding core city accessibility for high-income households $(<60$ minutes commuting time) or regarding lot-price constraints for low-income households that prefer single family houses $\left(220 € / \mathrm{m}^{2}\right)$. 
Fig. 8:

Migration target choice probability distribution for suburban municipalities in the Greater Vienna region

$\left(1^{\text {st }}\right.$ sorted (descending) by choice probability $(\mathrm{CP})$ of high-educated migrants preferring low density areas, $2^{\text {nd }}$ sorted (ascending) by CP of low-educated migrants preferring low density residential areas and $3^{\text {rd }}$ sorted (ascending) by $\mathrm{CP}$ of high-educated migrants accepting urban residential areas).

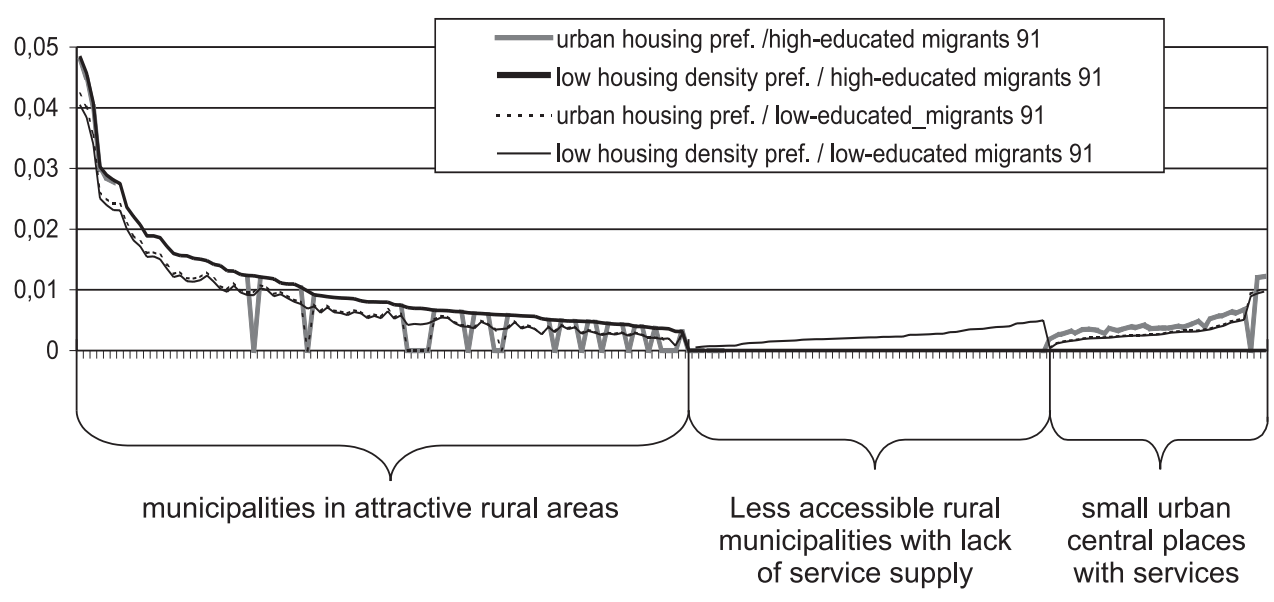

Fig. 8 shows the target choice probability distribution for the four defined household classes (as shown in Tab. 4), now sorted by choice probability of the different agent classes (see comments below figure title). The results reflect the effects of selection constraints: the target choice probability of (obviously) attractive municipalities for wealthy high-educated migrants is high, while a larger number of municipalities with lower attractiveness will not be accepted as future residence. The target choice probability for municipalities of lower-income migrants is definitely lower and is restricted to those migrants who prefer (or can afford) flats in multi-storey buildings. The choice probability for municipalities of high-income migrants that accept multi-storey buildings is higher for those municipalities which show higher levels of service infrastructure.

Figure 9 depicts the estimated spatial pattern of suburban target-choice probability of high-income/ high-educated migrants who prefer low-density residential areas surrounding the Vienna core city in 2015. The darker patches show attractive areas with highest in-migration probability (fulfilled if demand can be satisfied by supply). Not unexpectedly these areas correlate strongly with lot-price patterns within the region. An increase of the migration target choice probability between 2001 and 2015 can be observed for some areas north of Vienna. This is caused by expected better core city accessibility because of planned future motorways that will connect the Austrian districts along the Slovak and Czech border with the Vienna core city (cf. Loibl and Kramar, 2001). 
Fig. 9:

Migration target choice probability pattern for the Greater Vienna region 2015

(Loibl and Kramar (2001))

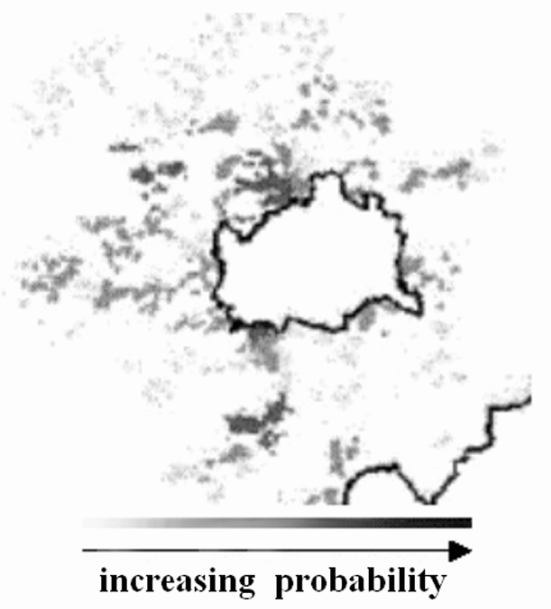

\section{Simulation of households' residential area search}

\subsection{Households' regional search: migration target municipality choice}

The target municipality choice is performed agent by agent: a target municipality is picked by each agent randomly out of the agent class's choice probability distribution. The agent class fractions of the total set of migrating households can be defined within the model interactively. Currently high-educated migrants make up about $25 \%$ of the total suburban migrants. The migrants' ratio of single family home seekers vs. multi-storey building seekers is predefined with 60\%:40\% (based on prior housing statistics analysis) but can also be modified interactively for future model scenarios. The decision of each household agent to migrate is taken once- one target municipality will be selected-inside this municipality the further search is performed considering the local attractiveness criteria. (cf. Chapter 3.2)

Model runs for the validation period 1971 to 2001 have to consider 120.000 suburban migration movements (cf. Tab. 1), which requires the simulation of a migration target choice for 40.000 household-agents (assuming an average household size of 3 persons). The model results are achieved with the simulation of household migration movements divided into 4 household classes (as defined in Tab. 4). Exact figures of the four agent classes do not exist as there are no interaction data sets provided on that level. But as all household agents occupy and densify residential area in total the overall validity of the model results can easily be observed by comparing the residential area growth simulation results 1968-1999 with the observed residential area size of 1999 as shown below. 
Fig. 10:

Comparison of modelled and observed residential area growth 1968-1999 per municipality in the Mödling district south of Vienna (Loibl and Tötzer. (2003))

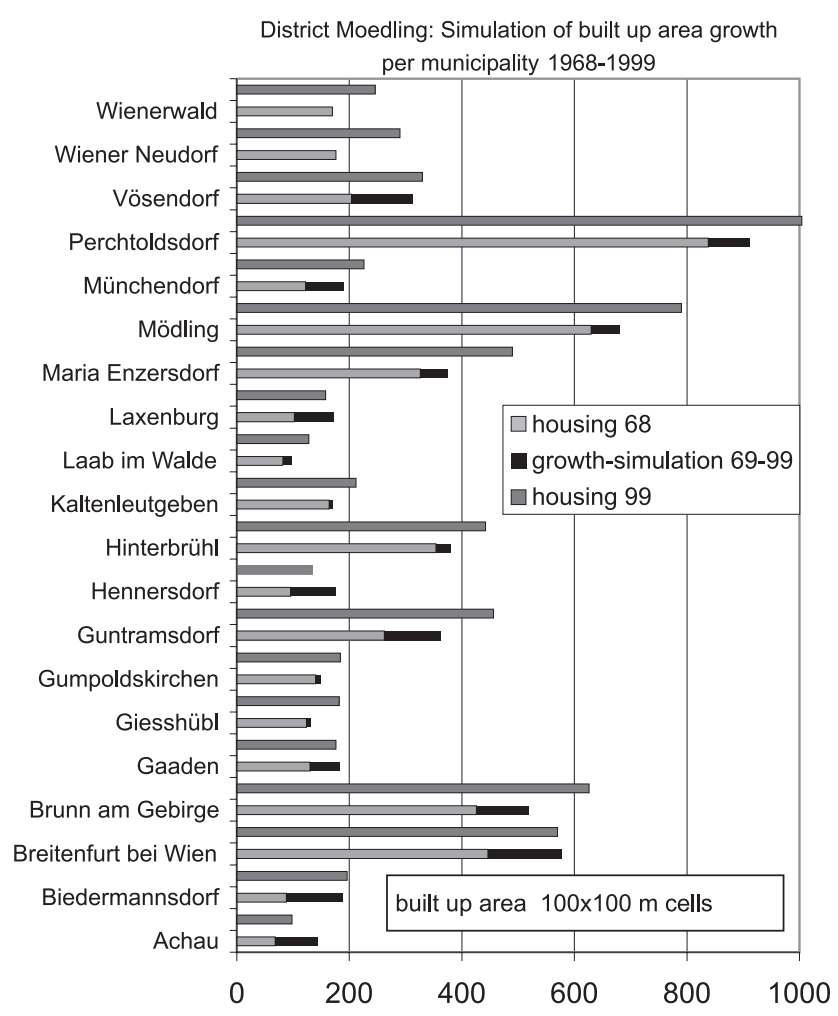

Figure 10 allows this verification for Mödling - a prosperous district south of Vienna with some 20 municipalities out of 180 . This comparison provides a better examination than single statistical measures like the correlation coefficient $r^{2}$, as it allows checking the absolute coincidence of observations and model results. (If there is for instance a uniform bias between observation and model results it can not be detected by the $r^{2}$ ). In this Fig. 10 the residential area of each municipality is shown by two bars. The upper bar (dark grey) shows the municipality's residential area in 1999, the lower bar (light grey) shows the residential area in 1968. The black bar extending the 1968 bar indicates the growth of residential area within the respective municipality. When both lower bars of one municipality reach a similar length as the upper observation bar, this proves the coincidence of the simulation results with the observations. As the figure shows, the growth simulations referring the residential area meet the observations at municipality level very well. (Land-use patterns for 1968 and 1999 derived from available satellite data are similar with those in 1971 and 2001, respectively. Therefore they can be related to migration numbers of the population census results 1971 to 1991). 


\subsection{Households' local search: residential area selection}

The migration target choice simulation at municipality level is the major step to reach high simulation accuracy in poly-centred regions. But the migration action of a household agent has to be continued until a proper lot, house or flat is found within a residential area of the selected municipality. This action can only be finished as far as the housing demand meets the housing supply: if an appropriate lot or flat in a suitable and attractive neighbourhood can be occupied. Thus this task might not interest in the context of regional demography but is necessary within a micro-simulation context. Therefore an overview shall help to understand the local effects and the feedback to migrants moving later.

After the selection of the target municipality, the search for an appropriate residential area will be continued within the municipality. The local search takes place in the cellular model landscape and consists of several steps. The local search of households depends on corresponding desires of the different agent classes regarding housing type and population density and local attractiveness including the neighbouring land-use pattern.

So the search is carried out by two alternative ways. Households belonging to agent classes that prefer single family houses start their search in a random cell in open space landscape within the selected municipality. The household agent moves to the nearest settlement border and seeks for residential area cells that show a potential population density appropriate for single family houses, or at least show open space cells with residential zoning, adjacent to residential areas. Households belonging to agent classes that accept or can only afford flats in multi-storey buildings start their search in the centre of the selected municipality and move in random direction in search of a cell with the lowest potential population density above a threshold appropriate for multi-storey buildings. Low population density indicates the availability of vacant flats or lots and sufficient attractive green space.

The constraints regarding search of a local population density minimum $d$ at time step $t$, is:

$$
f(d)=\left\{\begin{array}{l}
\left(d_{t}>0\right) \wedge\left(d_{(t+1)}-d_{t}>0\right): 1 \\
\left(d_{t} \leq 0\right) \wedge\left(d_{(t+1)}-d_{t} \leq 0\right): 0
\end{array}\right\}
$$

where

$d_{t} \quad=$ the actual cell population density and

$d_{(t+1)}-d_{l}=$ the possible future population density increase between $\mathrm{t}$ and $\mathrm{t}+1$ (the vacancies, ready to be "occupied" by new migrants.)

After reaching this minimum density cell $s$ a neighbourhood $S_{j}$ within an extent of $(+/-8)$ cells surrounding the minimum density cell will be defined.

$$
\mathrm{S}_{\mathrm{j}}=\left\{(x, y) \mid\left(x_{j-\text { extent }}<x_{j}<x_{j+\text { extent }}\right) \wedge\left(y_{j-\text { extent }}<y_{j}<y_{j+\text { extent }}\right)\right\}
$$

Within set $S_{j}$ (the neighbourhood square covering $17 \times 17\left(=17^{2}\right)$ cells surround- 
ing the selected population density minimum cell), a search for more attractive cells is carried out by examining additional attractiveness criteria $c_{g}(\mathrm{~g}=1 . .9)$, which are: (1) population growth potential which is the hypothetic population density increase based on the actual and a targeted population density maximum in the respective cell, (2) current neighbouring land use, (3) zoning regulations, (4) distance to nearest residential area, (5) distance to (motorway (weighted by traffic load), (6) distance to major road junctions, (7) number of neighbouring residential cells, (8) number of neighbouring industry cells, (9) number of neighbouring open space cells.

The examination needs a normalisation of the set of the attractiveness characteristics:

$$
C \rightarrow C^{*}
$$

The normalised characteristics $\mathrm{c}_{g}{ }_{g}$ are weighted regarding their importance with respect to the agents' specific attractiveness preferences, applying weights $w_{g, k}$ for each characteristic $c^{*}{ }_{g}$ related to the respective socio-economic agent class $k$. The normalised and weighted attractiveness criterion $\mathrm{c}^{*}{ }_{\mathrm{g}} \cdot w_{g, k}$ conducts each cell's total attractiveness $a_{j, k}$ as perceived by each household agent class $k$ :

where

$$
a_{j, k}=\sum_{j=1}^{n} \sum_{g=1}^{9} c_{j, g, k}^{*} \cdot w_{g, k}
$$

$a=$ attractiveness per cell $j$ and agent class $k$

$j \quad=$ index of investigated cell in the neighbourhood, $\left(j=1 . .17^{2}\right)$

$g=$ index of attractiveness criteria, $(g=1 \quad \ldots 9)$

$k=$ household agent class, $(k=1 \ldots 4)$

Thus all $a_{j, k}$ contains the total attractiveness of the respective cell $j$ for agents $k$. The "ultimate attractive" cell is the one with the maximum attractiveness total $a_{\text {final }, k}$ for the respective agent class $k$, where $a_{f i n a l, k}$ is preferred against $a_{l, k} \ldots$ against $a_{n, k}$ :

$$
a_{j_{1}, k} \subset a_{j_{2}, k} \subset \ldots \subset a_{j_{n}, k} \quad\left(j=1 \ldots 17^{2,}, k=1 \ldots 4\right)
$$

The cell with total attractiveness $a_{\text {final, } k}$ is selected by the agent of class $k$. If the individual household's search is successful, the household will settle and the population density in the respective cell increases by household size (and if necessary/possible, the land use class will change). If the search is not successful, up to 50 search attempts are carried out within the already selected municipality, if still not successful a different municipality is picked from the probability distribution and the search starts again.

As each agent's action changes local attractiveness it influences the decision of future moving agents. A blackboard serves as communication media to transport messages between already moved agents and agents that are seeking a residential area so new movers can learn from the experience of successfully migrating previous 
agents: new movers search in a first step near "landscape cells" where the last movers have settled successfully, otherwise they search longer and settle more scattered.

\subsection{Verification of local search results}

The local search results of socio-economic household agents cannot be verified due to lack of migration interaction data below municipality level. Therefore the verification is performed by comparing the municipality's simulated residential area growth with the observed land use 1999. Figure 11 shows the residential area pattern in black in some municipalities of the Mödling district south of Vienna.

Fig. 11:

Initial land use 1968 and comparison of observed land use 1999 with simulated land use 1999 for some municipalities in the Mödling district south of Vienna (some land use classes are combined to allow grey-scale presentation)

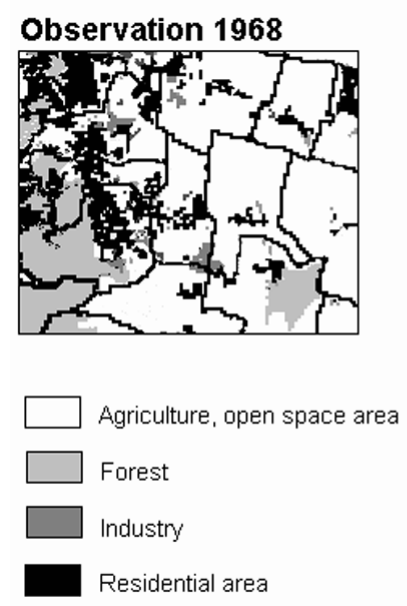

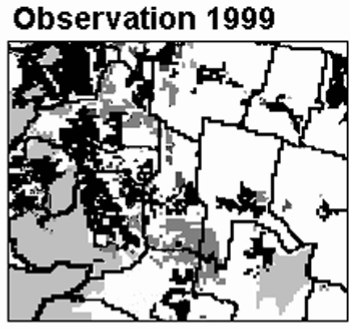

Simulation 1999

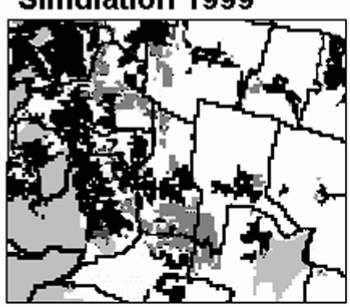

It can be noticed that the built-up area pattern of both 1999 maps show a high spatial coincidence, which proves that the defined migration behaviour rules will yield realistic household movement simulations which generate valid residential area patterns. Hot spots of residential area growth between 1968 and 1999 in the Mödling district are the municipalities Mödling, Maria-Enzersdorf, Brunn am Gebirge and Biedermannsdorf.

Future scenario simulation runs are performed for a 10 -year-period ending in 2011 (cf. Loibl and Tötzer (2003)). Several zoning and residential density restrictions are applied in order to document different sprawl effects triggered by different city planning guidelines. Thus it can be observed that restrictive residential area zoning and higher residential density targets can lead to a remarkable decrease of suburban sprawl speed, even if the numbers of migrating households remain the same. 


\section{Conclusion}

Applying this multi-agent system approach, the simulation yields accurate results for migration and residential area occupation which can be verified in detail by the observed urban sprawl pattern. The general migration patterns show very stable conditions as they refer to the migration target municipality choice probabilities for the various agent classes.

The crucial point is to identify and later quantify the spatial criteria influencing the migration target choice and to quantify the appropriate migration behaviour characteristics for the different socio-economically distinguished household classes at the local scale. If less appropriate attractiveness criteria are applied and "wrong" behaviour rules or municipality choice and target search processes are selected, the simulation results deviate significantly from observations. Here intensive tests are necessary to adapt the weights and parameters in order to achieve proper results. A future work will concentrate on model tests with different parameters and on model application to carry out control and scenario model runs for different suburban regions to provide decision support for planning activities in the surroundings of various cities.

\section{Acknowledgements}

The presented model was developed for the Project „STAU-Wien“ - Stadt-Umlandbeziehungen in der Region Wien: Siedlungsentwicklung, Interaktionen und Stoffflüsse; (city - suburb relations and settlement development in the Greater Vienna region) which was funded by the Austrian Ministry for Education, Science and Culture. The author wants to thank his colleagues-above all Rudolf Giffinger and Hans Kramar from the Technical University Vienna—for their contributions regarding accessibility modelling and Tanja Tötzer from ARC systems research for their spatial and statistical analysis of demography and housing data.

\section{References}

Batty, M., E. Besussi, N. Chin. 2003. Traffic, Urban Growth and Suburban Sprawl. CASA Working paper series No. London: Centre for Advanced Spatial Analysis. University College London. http://www.casa.ucl.ac.uk/working_papers/ paper70.pdf

Brake, K., J. Dangschat and G. Herfert (ed.). 2001. Suburbanisierung in Deutschland. Opladen: Leske und Budrich.

Becker, G. S., 1975, Human Capital. Chicago: Univ. of Chicago.

Bogue, D. J. 1969. Principles of Demography. New York: Springer. 
By og Byk (Danish Building and Urban Research Institute). 2003. Residential preferences, choice of housing, and lifestyle. http://www.by-og-byg.dk/english/publishing/summary/phd_tka.htm

Cheshire, P. C., S. Lanfranco, A. A. Summers. 1999. Urban Change in the United States and Western Europe-Comparative Analysis and Policy. Washington: Urban Institute Press.

Franklin, S. and Graesser, A. 1996. Is it an Agent, or just a Program?: A Taxonomy for Autonomous Agents. In: Proceedings of the 3rd Int. Workshop on Agent Theories, Architectures and Languages. Berlin: Springer-Verlag. pp. 21-35. http://www.msci.memphis.edu/ ranklin/AgentProg.html

Goetz, S. J. 2003. Migration and Local Labor Markets. In: "The Web Book of Regional Science”. Regional Research Institute, West Virginia University http://www.rri.wvu.edu/WebBook/Goetz/contents.htm.

Haynes, K. E. and Fotheringham, A.S. 1984. Gravity and Spatial Interaction Models. London: Sage-Publications.

Horstmann, K. 1976. Zur Soziologie der Wanderung, Soziale Schichtung und Mobilität. In: König R.(ed.), Handbuch der empirischen Sozialforschung. Stuttgart: Enke Verlag. pp.104-168

Landale, N. S. and Guest, A. M. 1985. Constraints, satisfaction and residential mobility: Speare's model reconsidered. Demography 22 (2). pp.199-222.

Lee, B. A., R. S. Oropesa and J. W. Kanan. 1994. Neighborhood context and residential mobility. Demography 31 (2). pp. 249-70.

Loibl, W. and Kramar, H. 2001. Standortattraktivität und deren Einfluss auf Wanderung und Siedlungsentwicklung In: Strobl J, Blaschke, T. and Griesebner G. (eds). Angewandte Geographische Informationsverarbeitung XIII. Heidelberg: Wichmann Verlag. pp. 309-315.

Loibl, W., R. Giffinger and S. Sedlacek (eds.) 2002. „STAU-Wien“ Stadt-Umlandbeziehungen in der Region Wien: Siedlungsentwicklung, Interaktionen und Stoffflüsse; Endbericht - Teil B: Daten, Theorie, Methoden und Ergebnisse. Seibersdorf: ARC seibersdorf research Report, ARC-S-0181.

Loibl, W. and Tötzer, T. 2003. Modeling growth and densification processes in suburban regions - simulation of landscape transition with spatial agents. Environmental Modelling and Software. 18 (6). pp. 485-593.

Lienenkamp R. (1999): Internationale Wanderungen im 21. Jahrhundert. Dortmunder Beiträge zur Raumplanung. Bd. 93. Dortmund: Inst. f. Raumplanung.

Kearns, A. and Parkes, A. 2002. Living in and Leaving Poor Neighbourhood Conditions in England. Centre of Neigbourhood Research, NR Paper 8. http://www.neighbourhoodcentre.org.uk/research/cnrpaperspdf/cnr8paper.pdf

Portugali, J. 1999. Self organization and the City. Heidelberg: Springer-Verlag.

Ruppert K. and Schaffer, F. 1969. Zur Konzeption der Sozialgeographie. Geographische Rundschau, Jg. 21 Heft 6. pp. 205-213. 
Steinnocher, K., F. Kressler and M. Köstl. 2000. Erstellung einer Siedlungsmaske aus Fernerkundungsdaten und Integration zusätzlicher Information aus Zensusdaten. In: Strobl, J., Blaschke T. (eds.). Angewandte Geographische Informationsverarbeitung XII. Heidelberg: Wichmann Verlag. pp. 481-488.

Stillwell, J., and Congdon, P. (Eds.) 1991. Migration models: macro and micro approaches, London: Belhaven Press.

Torrens, P. 2001. Can Geocomputation Save Urban Simulation? Throw some agents into the mixture, simmer and wait ...; CASA working paper series No. 32. London: Centre for Advanced Spatial Analysis. University College London. http://www.casa.ucl.ac.uk/working_papers/paper32.pdf 